\title{
A new green-coloured Lusitanipus Mauriès, 1978 from the Iberian Peninsula (Diplopoda: Callipodida: Dorypetalidae)
}

\author{
José D. GILGADO ${ }^{1, *}$, Virginia MARTÍNEZ-PILLADO ${ }^{2} \&$ Carlos E. PRIETO $^{3}$ \\ ${ }^{1}$ Section of Conservation Biology, Department of Environmental Sciences, \\ University of Basel. St. Johanns-Vorstadt 10, CH-4056, Basel, Switzerland. \\ ${ }^{2}$ Centro Mixto UCM-ISCIII de Evolución y Comportamiento Humanos. \\ Avenida del Monforte de Lemos, 5. Pabellón 14. E-28029, Madrid, Spain. \\ ${ }^{3}$ Departamento de Zoología y Biología Celular Animal, Facultad de Ciencia y Tecnología, \\ Universidad del País Vasco, Apdo. 644, E-48080, Bilbao, Bizkaia, Spain. \\ *Corresponding author: josedomingo.gilgadohormaechea@unibas.ch \\ ${ }^{2}$ Email: vmpillado@gmail.com \\ ${ }^{3}$ Email: carlos.prieto@ehu.eus \\ ${ }^{1}$ urn:Isid:zoobank.org:author:A1AD54CE-377D-4A62-8C21-769CDB48C6B2 \\ ${ }^{2}$ urn:1sid:zoobank.org:author:A5DBED4D-381A-47B0-B3B8-6C7954D8CFDC \\ ${ }^{3}$ urn:1sid:zoobank.org:author:CAC20D21-78FF-4B8A-8023-F06A06EA031F
}

\begin{abstract}
Recent samplings in cavities of the Iberian Peninsula led to the discovery of a new millipede species of the order Callipodida in one cave in the region of El Bierzo (León, Spain): Lusitanipus xanin sp. nov. In additional samplings (near that cave), more specimens of this new species were discovered in surface habitats. The species has various distinctive characteristics, such as its green colour, but the morphology of the gonopod has several similarities with that of Lusitanipus alternans (Verhoeff, 1893), indicating a close relationship between them. The diagnosis of the genus Lusitanipus Mauriès, 1978 has to be changed to accommodate the new species. The presence of crests in two different sizes is no longer a diagnostic character of the genus Lusitanipus, but of the species L. alternans. Lusitanipus xanin sp. nov. is the fourth species of the order Callipodida for the Iberian Peninsula, and the second species for the genus. Lusitanipus xanin sp. nov. seems to be an epigean but troglophile species.
\end{abstract}

Keywords. El Bierzo, Myriapoda, new species, troglophile, Xanín.

Gilgado J.D., Martínez-Pillado V. \& Prieto C.E. 2020. A new green-coloured Lusitanipus Mauriès, 1978 from the Iberian Peninsula (Diplopoda: Callipodida: Dorypetalidae). European Journal of Taxonomy 714: 1-14 https://doi.org/10.5852/ejt.2020.714

\section{Introduction}

Diplopoda (millipedes) is a highly diverse class of detritivore arthropods that play an important role in soil formation and the cycle of nitrogen by consuming decaying plant material, including leaf litter (Golovatch \& Kime 2009, Cárcamo et al. 2000, David 2015). Despite its diversity and relevance, it is an understudied group compared to arachnids and insects (Brewer et al. 2012). While Europe is one 
of the regions where the millipede fauna is best known, not all the regions have received the same amount of attention. One of the main "gaps" in millipede knowledge is the Iberian Peninsula. This has been highlighted by authors such as Spelda (2015), who stated that this peninsula is "terra incognita" regarding its millipede fauna. In two volumes of the Atlas of European Millipedes by Kime \& Enghoff (2011, 2017), dealing in total with eight millipede orders, the authors compile in each volume a map of Europe marking $50 \times 50 \mathrm{~km}$ squares with at least one millipede record. In those maps, one can see that there are large areas in the interior of the Iberian Peninsula that are lacking any record, whereas in Central Europe there are only a few "blank" areas. Nevertheless, in the last decade, the interest in the millipede fauna of the Iberian Peninsula has increased, and several descriptions of new species have been made from specimens captured in caves (e.g. Enghoff \& Reboleira 2013; Reboleira \& Enghoff 2014; Mauriès 2013, 2014; Djursvoll 2019), shallow subterranean habitats (Gilgado et al. 2015a, 2015b, 2017; Akkari et al. 2018), and on the surface (e.g. Akkari \& Enghoff 2012, 2017; Mauriès 2018; Recuero \& Rodríguez-Flores 2020). Further initiatives, such as a series of samplings in caves of northern Spain by one of the authors of the manuscript (C.E.P.), have resulted in the discovery of a new millipede of the order Callipodida, subject of the present work.

Callipodidan millipedes are usually found in rocky environments, such as caves and crevices, and can be considered petrophilic (Stoev et al. 2008). Some species have only been found in caves, but just a few of them actually show troglobiomorphic characters (Stoev et al. 2008; Spelda 2015). Although millipedes are detritivores, feeding on decaying plant tissues, several exceptions have been found within Callipodida (Stoev et al. 2008). These exceptions include species that have been observed to feed on different types of arthropods and even practice cannibalism. The order Callipodida includes around 140 species worldwide (Stoev et al. 2008; Spelda 2015; Stoev 2015), of which 53 occur in Europe (Kime \& Enghoff 2011) and, up to now, three in the Iberian Peninsula. The knowledge on these three species is summarised by Spelda (2015). These three species belong to the same family (Dorypetalidae), but each of them belongs to a different monospecific genus. The most frequent and widespread species seems to be Cyphocallipus excavatus Verhoeff, 1909, recorded in many locations close to the littoral in Andalusia (southern Spain). The rarest species, only known from the holotype and with a vague geographical location in its label referring to "southern Spain", is Dorycallipus arcuum Verhoeff, 1909. The third species, Lusitanipus alternans (Verhoeff, 1893), is found in several caves in central Portugal. While L. alternans appears in caves located along a relative wide area, it is only locally present inside them despite not showing evident signs of morphological adaptations to the subterranean environment, and it hasn't been found on the surface yet.

In 2006, the author C.E.P sampled a small cave in the province of León that resulted in the capturing of a male callipodidan millipede; in 2019, the other two authors, J.D.G. and V.M.P., sampled epigean environments in the same area and found an additional male and female of the same species. After closely examining their gonopods and other morphological characteristics, we concluded that it is a new species, different from the other three Iberian species of the order Callipodida but closely related to L. alternans. The gonopods fit the characteristics of the genus Lusitanipus Mauriès, 1978, but one character of the external morphology (metazonital crests being all of similar size) does not agree with the diagnosis of the genus. Therefore, the diagnosis of Lusitanipus needs to be changed to accommodate the new species, and that character is now a specific diagnostic one of L. alternans.

\section{Material and methods}

\section{Location}

The specimens were found close to the Peñarrubia reservoir (Fig. 1A), located along the course of the Sil river, in the northwestern part of the Iberian Peninsula (Fig. 1A), on the border of the province of Ourense (Galicia) and the region of El Bierzo, León (Castile and Leon, Spain). The reservoir forms part of the Galician-Leonese Mountains and is constituted by Upper Ordovician dolomites and limestones 
(Abril Hurtado et al. 1982). The river Sil forms narrow canyons when crossing these mountain formations. The climate of the region is Mesomediterranean thermotype and the Subhumid ombrotype (Rivas-Martínez et al. 2011; Díaz González \& Penas 2017), and this is caused mostly because of the mountainous barrier that delimits the region. The weather is predominantly mild, generally warm and temperate, with annual averages of $12.6^{\circ} \mathrm{C}$ and $730 \mathrm{~mm}$ of precipitation (climate-data.org 2019). The first specimen was captured in a small cave near the entrance and close to the dam. The other two specimens were captured approximately $1 \mathrm{~km}$ north of that location under stones in soil, rocky debris and leaf litter beside the road parallel to the reservoir. This sampling point is situated in the east side of the reservoir, at an altitude of $406 \mathrm{~m}$ a.s.l., and in the base of a slope under some cliffs (El Rechouso). The sedimentary deposits in this margin are composed of detrital sediments of colluvial origin formed

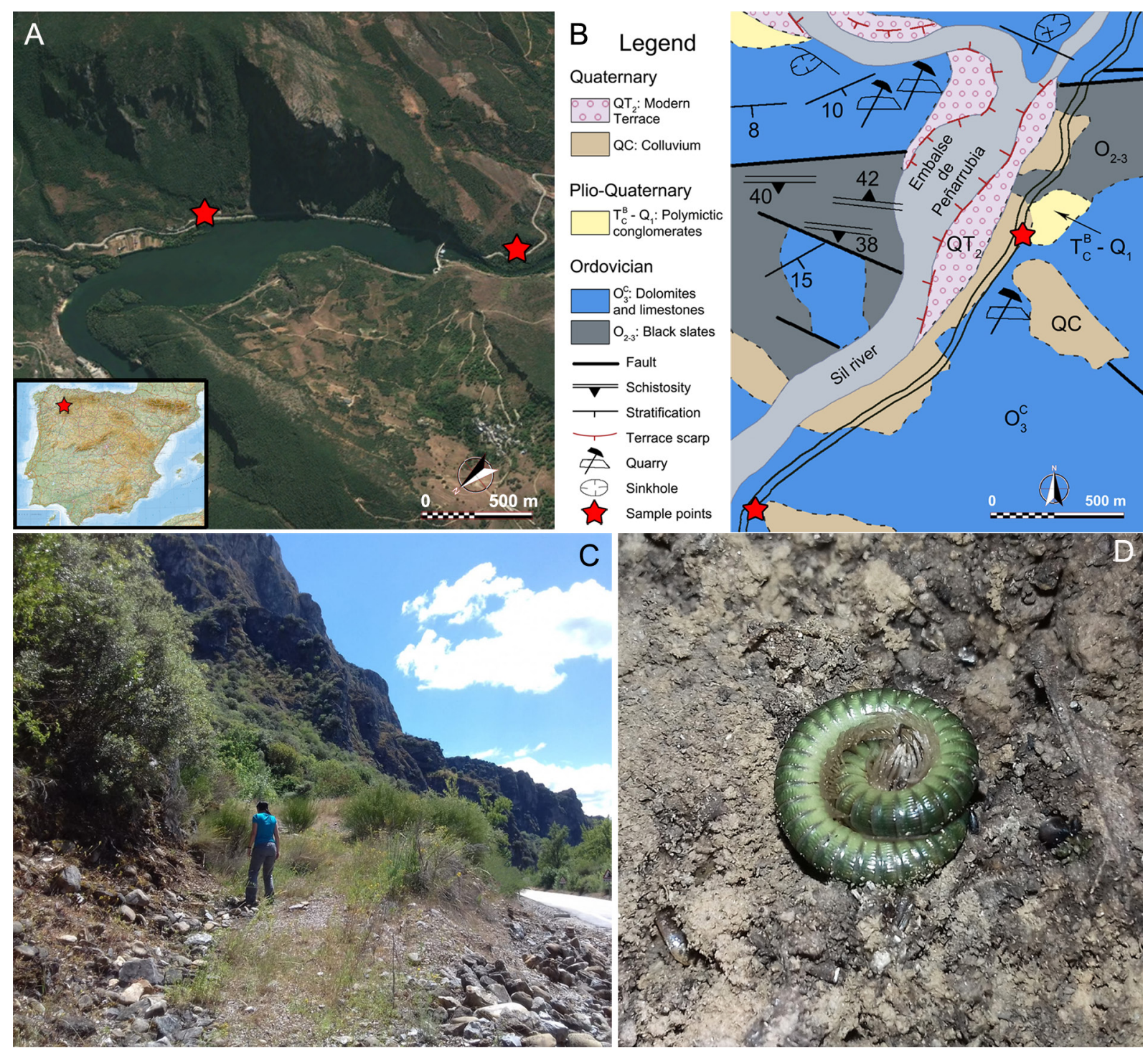

Fig. 1. Location and characteristics of the sampling points and a living specimen of Lusitanipus xanin sp. nov. A. Aerial view of the area at the Peñarrubia reservoir and its location in the Iberian Peninsula, with sampling point marked with a red star. B. Geological map of the area (modified from Abril Hurtado et al. 1982), with sampling point marked by a red star. C. Aspect of the landscape where Lusitanipus xanin sp. nov. was collected. D. Living specimen of Lusitanipus xanin sp. nov. in a defensive position over a clay layer below the limestone pebbles where it was found. 
by chaotic accumulations of clays and silts and eroded pebbles that had fallen from the surrounding lithologies (mainly limestones and dolomites) (Fig. 1B-C). This fine material, together with the decaying leaf litter, forms a moisture-preserving layer several centimetres thick (Fig. 1D). The vegetation in the surroundings of the sampling point is composed by a dense mixed forest composed of small trees and shrubs, with several mediterranean species such as Quercus ilex, Lonicera sp. Phillyrea angustifolia, Pistacia terebinthus and Cytisus scoparius.

\section{Study method and repository}

All the specimens were hand collected and stored in 75\% ethanol. The specimen from 2006 was dissected to observe the gonopods, and the first eight pairs of legs were mounted in a semi-permanent preparation for optic microscopy in dimethyl hydantoin formaldehyde (DMHF). The morphology was compared to the descriptions and pictures in Spelda (2015) and Reboleira \& Enghoff (2015). The specimens were prepared and photographed using a Leica M205 C and a Keyence VHX-6000 microscope, respectively. The type material is stored in the Museo Nacional de Ciencias Naturales (MNCN, Madrid, Spain).

\section{Results}

Order Callipodida Pocock, 1894

Family Dorypetalidae Verhoeff, 1900

Genus Lusitanipus Mauriès, 1978

Diagnosis as given in Reboleira \& Enghoff (2015), but a change needs to be made to accommodate the new species. The presence of setiferous metazonital crests of two sizes (primary crests and secondary crests) is no longer a diagnostic character of the genus Lusitanipus but only of the species Lusitanipus alternans. Therefore, Lusitanipus differs from Cyphocallipus Verhoeff, 1909 by the simple gonocoxite and straight rodlike gonopodal pseudoflagellum, and from Dorycallipus Verhoeff, 1909 by males not having the forehead flattened.

$$
\begin{aligned}
& \text { Lusitanipus xanin Gilgado sp. nov. } \\
& \text { urn:1sid:zoobank.org:act:2B1CB681-38B8-4F13-99B3-1DAFFE514367 }
\end{aligned}
$$

Figs 1D-6

\section{Diagnosis}

Lusitanipus xanin sp. nov. differs from the other Iberian callipodidan species in the same characters as Lusitanipus alternans (see Reboleira \& Enghoff 2015), except that Lusitanipus xanin sp. nov., has metazonital crests of similar size, whereas Lusitanipus alternans has crests of different sizes (Verhoeff 1893; Spelda 2015; Reboleira \& Enghoff 2015). Furthermore, Lusitanipus xanin sp. nov. differs from L. alternans in its green colour, the higher number of body rings, the shape of the gonocoxite, and the curvature and shape of the processes of the tip of telopodites of gonopods.

\section{Etymology}

The specific epithet xanin (noun in apposition) is the name of a goblin-like mythological creature, the "Xanín". This being supposedly inhabits the forests of the region were this species was found (E1 Bierzo). As the "Xanín", this species is a small creature dwelling on the ground under the shade of the foliage that is seldomly seen and tries to hide when discovered. 


\section{Type material}

\section{Holotype}

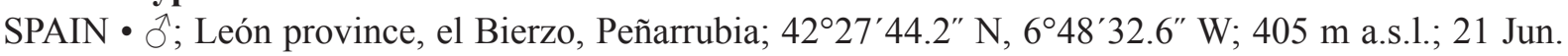
2019; José D. Gilgado and Virginia Martínez-Pillado leg.; slope beside the road parallel to the Peñarrubia reservoir; under stones; MNCN 20.07/2069.

\section{Paratypes}

SPAIN • 1 \% , same collection data as for holotype; MNCN 20.07/2070 • 1 đ, León province, el Bierzo, Peñarrubia; 42 $27^{\prime} 19.2^{\prime \prime} \mathrm{N}$, 6 6 $49^{\prime} 6.9^{\prime \prime} \mathrm{W}$; $430 \mathrm{~m}$ a.s.1.; 12 Oct. 2006; Carlos E. Prieto leg; entrance of small cave without name, close to the dam; MNCN 20.07/2071.

\section{Description}

Body sIzE. Holotype male: 60 body rings including collum, telson; two apodous rings before telson. Body approximately $50 \mathrm{~mm}$ long; $2.5 \mathrm{~mm}$ high; $2.3 \mathrm{~mm}$ wide at mid-body section. Paratype male: 62 body rings (two apodous); approximately $39.5 \mathrm{~mm}$ long; $2.2 \mathrm{~mm}$ high; $2.05 \mathrm{~mm}$ wide at mid-body section. Female: 63 rings (two apodous); $53 \mathrm{~mm}$ long; $2.8 \mathrm{~mm}$ high; $2.45 \mathrm{~mm}$ wide at mid-body section.

CoLour. Living specimens: intense green colour, dorsally darker, ventrally lighter (Fig. 1D). Dorsal median light stripe absent. In first body rings, prozonites lighter, posterior half of metazonites darker than anterior part, darker (brownish) crests than intercrests. Colour pattern subtly, progressively changing towards end of body, getting more even, mostly in prozonites; metazonites having more intense darker green colour (Fig. 2). Legs pale beige (Fig. 2). Antennomeres 2-5 pigmented in greyish colour, more in distal extremes; antennomeres 6-7 little or no pigmentation (Figs 2, 3B). Colour fading to paler brownish or greyish tone (Fig. 3A) after long-term storage in ethanol.

HEad. Convex, without flattened area or bumps of Cyphocallipus (Figs 2, 3A, C), covered with small setae, larger on forehead than posterior part of head. Posterior region having lighter colour than forehead (Fig. 3A, C). Eyes with ca 59 ommatidia distributed in eight rows (Fig. 3A). Tömosvary organ dorsally between eyes, insertion of antennae, closer to former, being only slightly larger than largest ommatidia. Antennomeres of similar shape, proportions to L. alternans, with 6-7 lacking pigmentation (Fig. 3B). Antennomere 5 distally, laterally with sensory region full of short, dense sensillae, also present in L. alternans and other Dorypetalidae species as Dorypetalum helenae (Stoev \& Enghoff 2006).

TRUNK. Collum: colour pattern as in Fig. 3C, not very marked crests. Five setae on each side of median half, with setae a,d-e in anterior position; $\mathrm{b}$ slightly more posterior than $\mathrm{a} ; \mathrm{c}$ slightly more posterior than $\mathrm{b}$ (Table 1). Chaetotaxy of first seven rings as in Table 1, all setae posterior from body ring 6. Prozonites with scale-like microsculpture, narrow, not very marked crest-like lines, not always continuous with crests of metazonite (Fig. 3D). Crests of metazonites equal in size, unlike L. alternans. Pleurotergite 7 with 18 crests on each side. In male holotype, ozopores present from ring 5 (very inconspicuous on this ring) up to ring 57. Ozopores placed between anterior extremes of $5^{\text {th }}-6^{\text {th }}$ crest, except first one: closer to $5^{\text {th }}$ crest.

Legs. First pair of smaller size than following, with bump on coxae. Second pair slightly larger, showing gonopores. Two first pairs having one macroseta on inner part of prefemora, bundles of macrosetae in inner side of femora, postfemora; in tarsus: brush-like row of setae on inner side (Fig. 4A-B). Leg 3 not having these bundles of macrosetae, instead: fields of small aggregated setae on inner side of prefemur, femur, postfemur. Leg 3 showing, under optic microscopy, brush-like row of setae on tarsus, papillae (Fig. 4C). Leg 3 with coxal sacs, conspicuous from legs 3-16, missing or not visible in following ones (Fig. 4C-D). Leg 4 seemingly without brush-like row of setae but with papillae, aggregated inner fields of setae on inner side of trochanter, prefemur, femur, postfemur (Fig. 4D-E). Same pattern repeated on 
all legs, except for last 15, lacking these papillae, fields of setae. Claws of all legs well developed, two basal minor spines (Fig. 4E).

TELSON (Fig. 3F). Epiproct with one spinneret, four setae at each side of sagittal plane, two most proximal setae in middle, two most distal ones close to posterior margin. Paraproct bipartite, with macroseta in each division, as in L. alternans. Hypoproct tripartite with $1+2+1$ setae.

MALE GONOPOdS (Fig. 5). Gonocoxite (c) simple, narrow, with almost semi-circular arc (arc) in middle part, row of setae on posterior margin, as seen in lateral view (Fig. 5B). Arc of gonocoxite ending in blunt semi-rectangular process ( $\mathrm{srp}$ ), almost as long as arc, narrower in central part, pilose on distal margins (Fig. 5A-C). Process flat on interior side, without "spoon-like" shape to accommodate telopodite. Pair of membranous structures $(m)$ of small size interiorly placed between bases of gonocoxites $(c)$, posteriorly to pseudoflagellum $(f)$, telopodites $(t)$. Membranous structures $(m)$ seemingly triangular shaped in posterior view, however in lateral view: subrectangular projection $(s p)$ in margin. Homologous structure

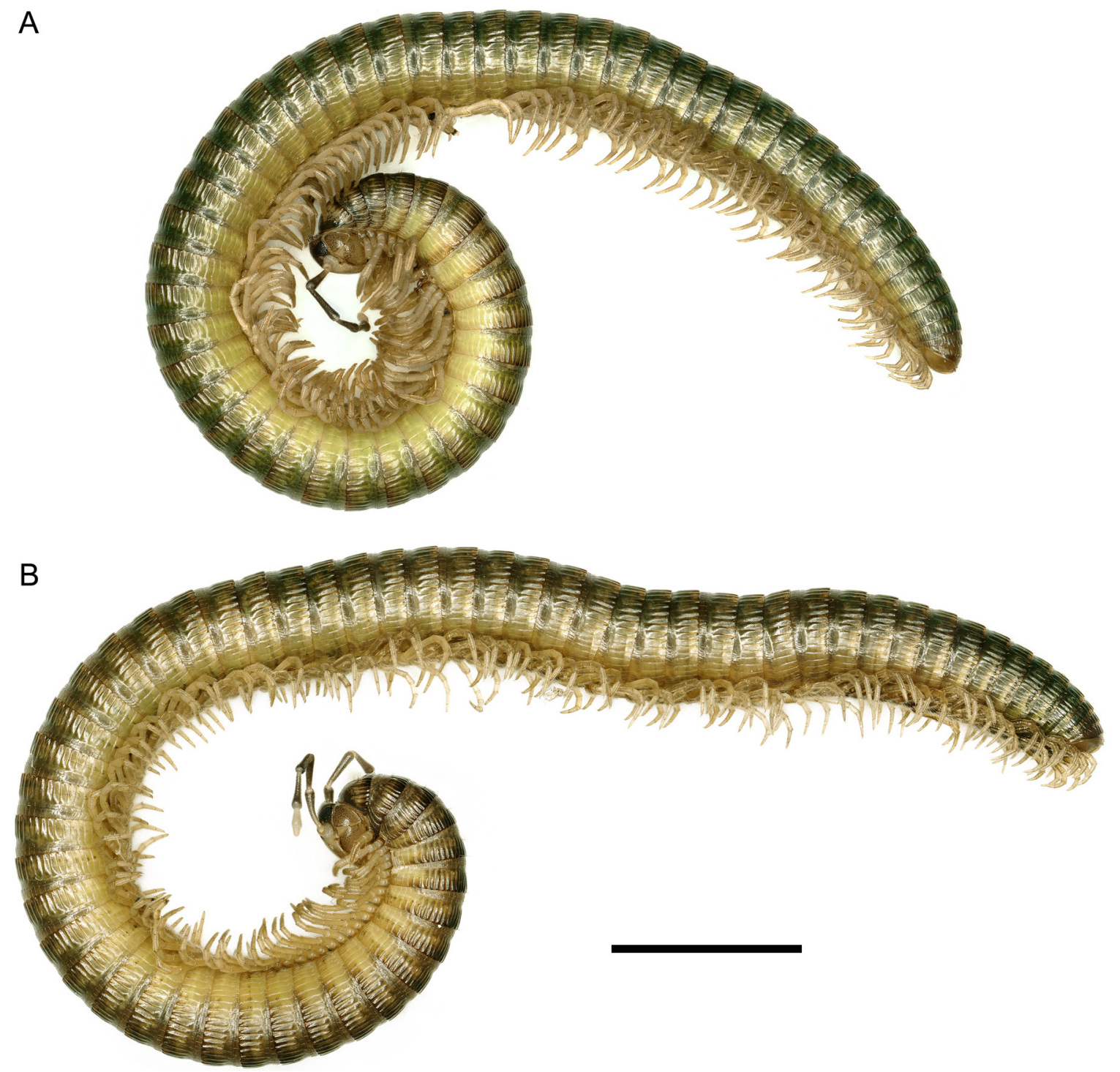

Fig. 2. External morphology of Lusitanipus xanin sp. nov. in lateral view. A. $\widehat{\jmath}$ holotype (MNCN 20.07/2069). B. + paratype (MNCN 20.07/2070). Scale bar $=5 \mathrm{~mm}$. 

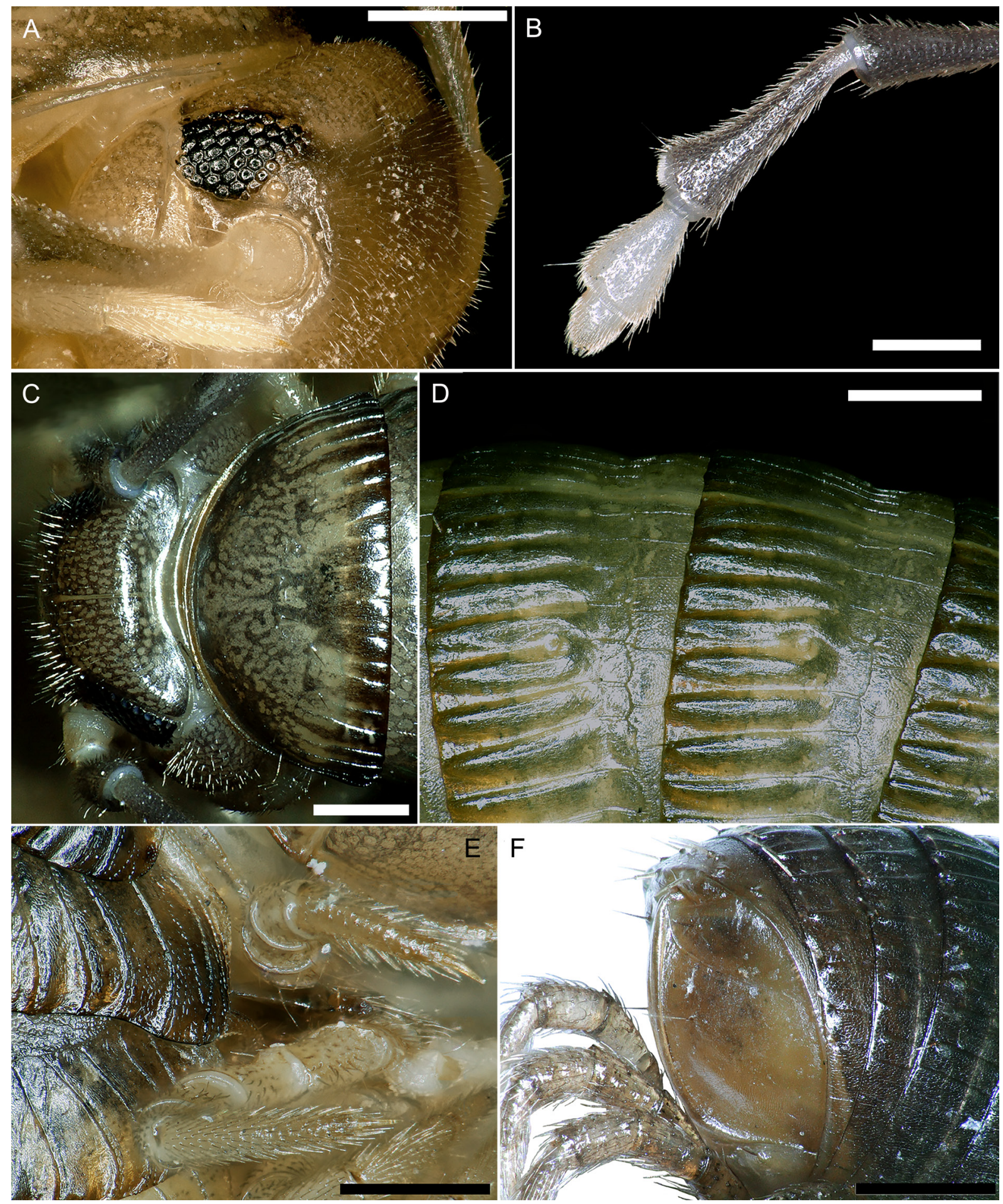

Fig. 3. Morphological details of Lusitanipus xanin sp. nov. A. Head of ô paratype (note: colour has faded after 13 years in ethanol) (MNCN 20.07/2071). B. Last antennomeres of 9 paratype (MNCN20.07/2070). C. Posterodorsal part of the head of 9 paratype and collum in dorsal view (MNCN 20.07/2070). D. Dorsal part of pleurotergites 5 (only partially visible) to 7 in lateral view (MNCN 20.07/2070). E. Detail of ventral part of first rings of $q$ in lateral view, with posterior tip of collum and pleurotergite 2 visible, four first pair of legs (second reduced) and coxal sacs (MNCN 20.07/2070). F. Telson and last rings of q paratype (MNCN 20.07/2070). Scale bars $=0.5 \mathrm{~mm}$. 
Table 1. Chaetotaxy of the first seven rings (pleurotergites) of Lusitanipus xanin sp. nov. Setae order (a-e), reflects proximity to sagittal plane, with (a) being the closest. (A) means anterior, (A*) means that it is close to the anterior position or in the middle, and (P) means posterior.

\begin{tabular}{cccccc}
\hline & a & b & c & d & e \\
\hline Collum 1 & A & A $^{*}$ & $A^{*}$ & A & A \\
Pleurotergite 2 & A & A & A & $A^{*}$ & A \\
Pleurotergite 3 & A & A & A & A & A \\
Pleurotergite 4 & A & A & A & A & A $^{*}$ \\
Pleurotergite 5 & A & P & P & $A^{*}$ & P \\
Pleurotergite 6 & P & P & P & P & P \\
Pleurotergite 7 & P & P & P & P & P \\
\hline
\end{tabular}

present in L. alternans in fig. 5A of Reboleira \& Enghoff (2015), with similar but slightly different shape. Pseudoflagellum (or hornflagellum) (f) straight, as in L. alternans, almost as long as telopodite $(t)$. Telopodite ending in complex structure similar to L. alternans, with several differences (Figs 5D-E, 6): tip of telopodite $(l)$ flat (as a lamella), curved in way that tip projecting towards solenomerite $(s)$, similarly to hook (Figs 5D, 6B). Same processes as L. alternans present, except for $\gamma$, having several differences (Fig. 6): $\alpha$ shorter, less twisted (only slightly curved in tip), placed more basally; $\beta$ short, not twisted, shape of solenomerite $(s)$ slightly different: narrow pointy process pointing anteriorly, shorter pointy tip projecting towards tip of telopodite.

Female. First pair of legs of smaller size compared to third pair of legs. Second pair of legs reduced (Fig. 3E). Second pleurotergite without conspicuous ventrolateral posteriad process as Cyphocallipus excavatus (see Hoffman 2009), margin describing subtle tentative insinuation of process in that position (Fig. 3E). Everted coxal sacs visible from third pair of legs, as male (Fig. 3E).

\section{Discussion}

The original drawing of the gonopod of L. alternans (Verhoeff 1900) did not allow for an accurate comparison with the structures described in the new species. These could however be identified and compared between the two species based additionally on information from SEM illustrations (Reboleira \& Enghoff 2015) despite minor differences in the orientation of the structures in the different representations (Figs 5-6). The gonopod morphology of Lusitanipus xanin sp. nov. is very similar to that of $L$. alternans, but there are differences in the shape of the gonocoxite and the tip of the telopodites (Fig. 6). These differences include the absence of $\gamma$ and a reduced $\beta$ process in Lusitanipus xanin sp. nov. (Figs 5, 6D-E) and the different curvature of the lamella (l) (Fig. 6B, E), the most distal part of the telopodite (Fig. 6A-B, D-E). Apart from the gonopod morphology, there are three main different characters in the external morphology: the green colour of the specimens, the higher number of rings, and the uniform size of the crests. The origin of the green colour is unknown, but the fact that it fades and eventually disappears after long term storage in ethanol points to some kind of pigment. The biological meaning of the green colour (e.g. camouflage, a collateral effect of storing some substance, etc.) is also unknown, but this kind of pigmentation is unusual and worth mentioning in millipedes. Up to date, there are no other green coloured European millipede species, but there are green or greenish millipedes in other continents, such as the sphaerotheriid Zoosphaerium neptunus (Butler, 1872) native to Madagascar (see for example Wesener \& Wägele 2008), some Tasmanian spirostreptid species of the genus Amastigogonus Brölemann, 1913 (see Mesibov 2007), some North American spirobolid species (see for example Causey 1955), and various Central American Rhacodesmid millipedes (see 
for example Loomis 1976). The number of rings in the studied specimens is larger than in L. alternans (Reboleira \& Enghoff 2015), but similar to or non-significantly higher than in other Iberian species. For example, C. excavatus has 59-60 rings according to Hoffman (2009). The reason for this larger number in Lusitanipus xanin sp. nov. in comparison with L. alternans is not known. The uniform size of the crests in Lusitanipus xanin sp. nov. is remarkable, since the bimodal size of the crests in L. alternans was used as a diagnostic character of the genus Lusitanipus. However, the gonopod resemblances between the newly discovered species and L. alternans indicate a close phylogenetic relationship, which is also supported by their geographical proximity. These resemblances speak against creating another monospecific genus for the new species. The diagnostic characters for the genus Lusitanipus are now as stated in the taxonomy section.

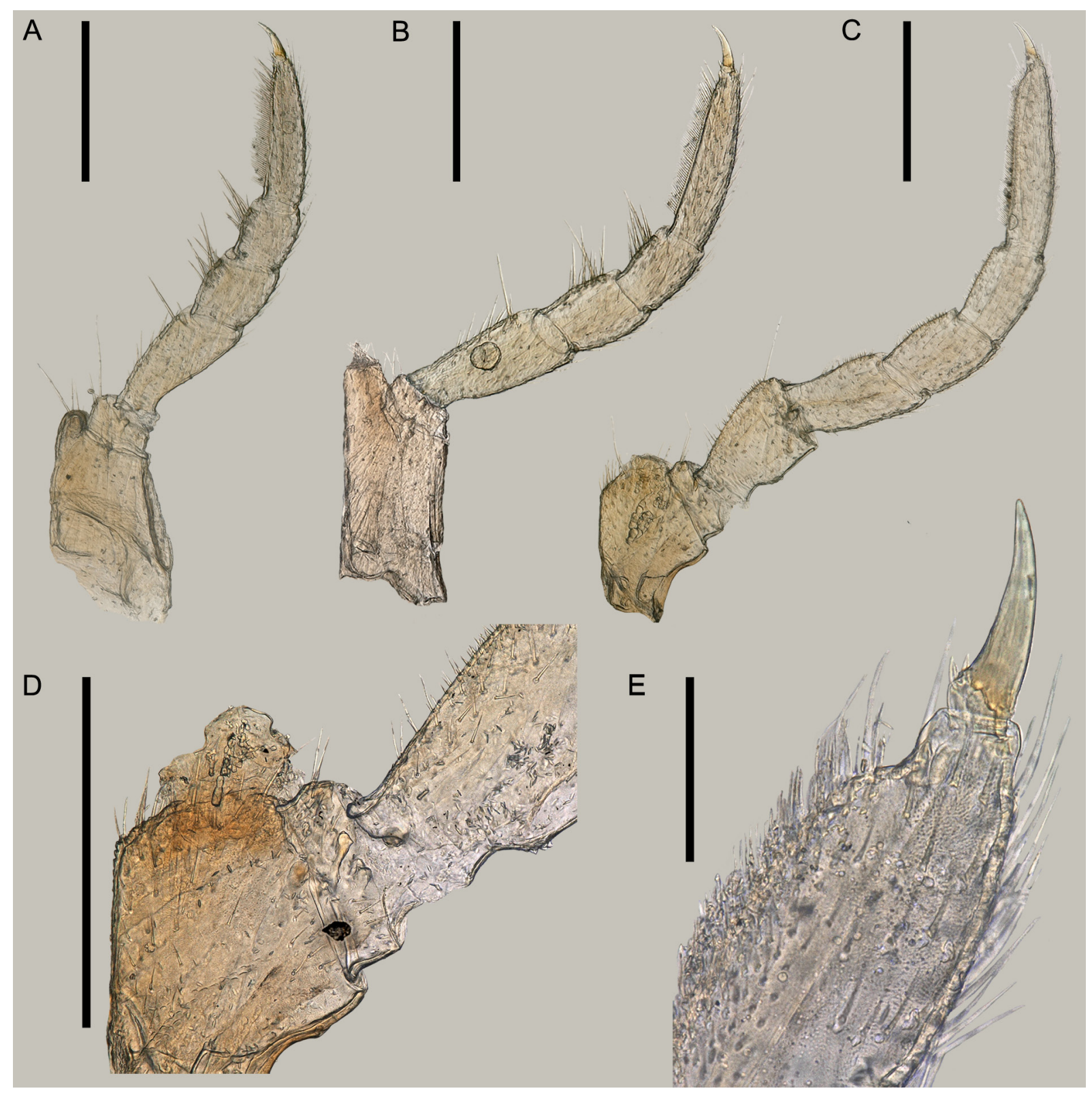

Fig. 4. Legs of ô paratype (MNCN 20.07/2071) seen by optic microscopy. A. Leg 1. B. Leg 2. C. Leg 3. D. Coxa and coxal sac of leg 4. E. Tip of tarsus and claw of leg 4. Scale bars: A-D $=0.5 \mathrm{~mm}, \mathrm{E}=0.1 \mathrm{~mm}$. 


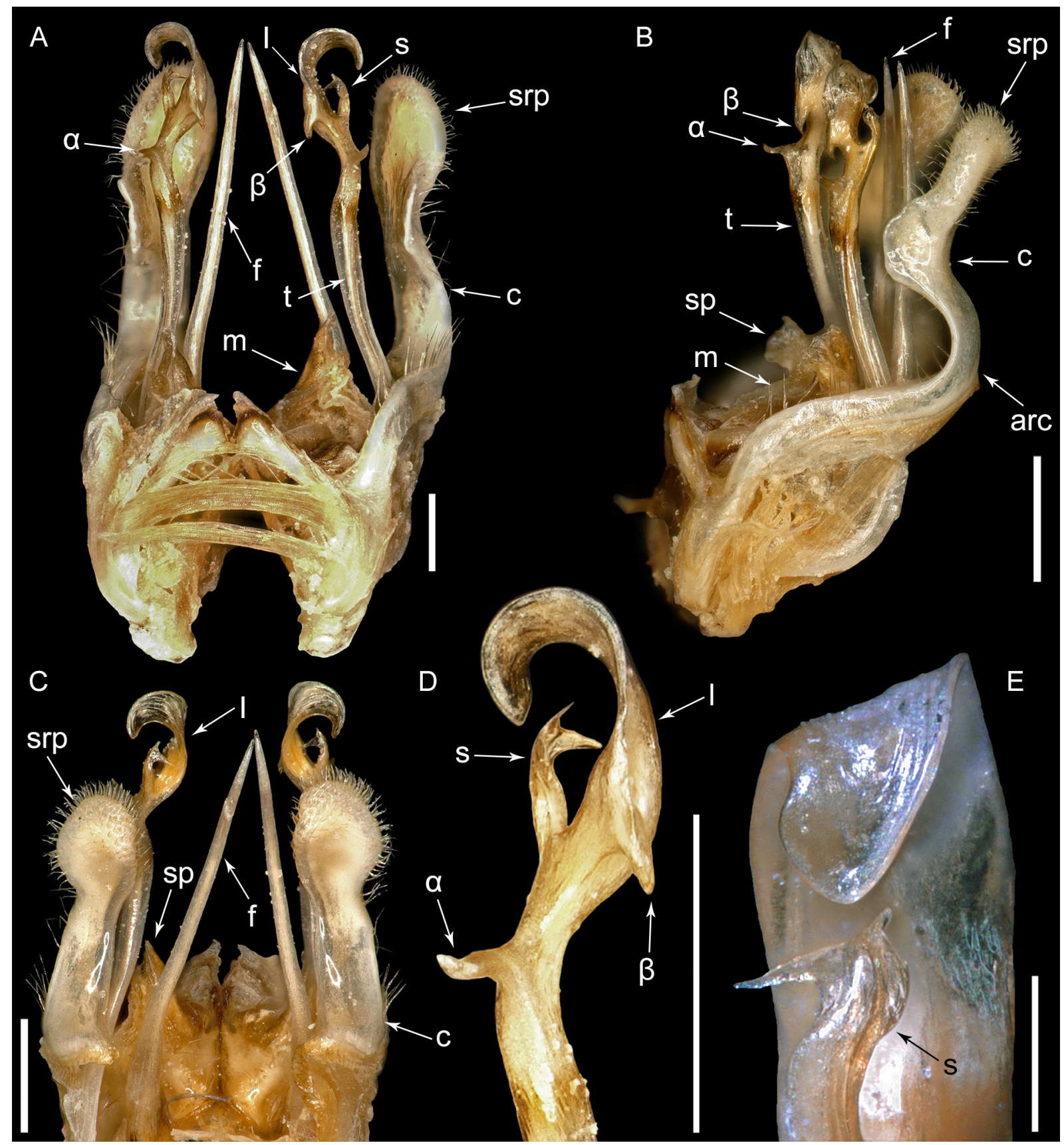

Fig. 5. Gonopod of $\widehat{o}$ paratype (MNCN 20.07/2071). A. Posterior view. B. Lateral view. C. Anterior view. D. Distal part of right telopodite in posterior view. E. Tip of right telopodite with tip of solenomerite visible. Scale bars: $\mathrm{A}-\mathrm{D}=0.4 \mathrm{~mm}, \mathrm{E}=0.1 \mathrm{~mm}$. Abbreviations: $\alpha, \beta=$ processes of telopodite; arc $=$ semi-circular arc of gonocoxite; $c=$ gonocoxite; $f=$ pseudoflagellum (or hornflagellum); $l=$ lamella; $m=$ membranous structures; $s=$ solenomerite; $s p=$ subrectangular projection of membranous structures; $s r p=$ semi-rectangular process of gonocoxite; $t=$ telopodite. 
A

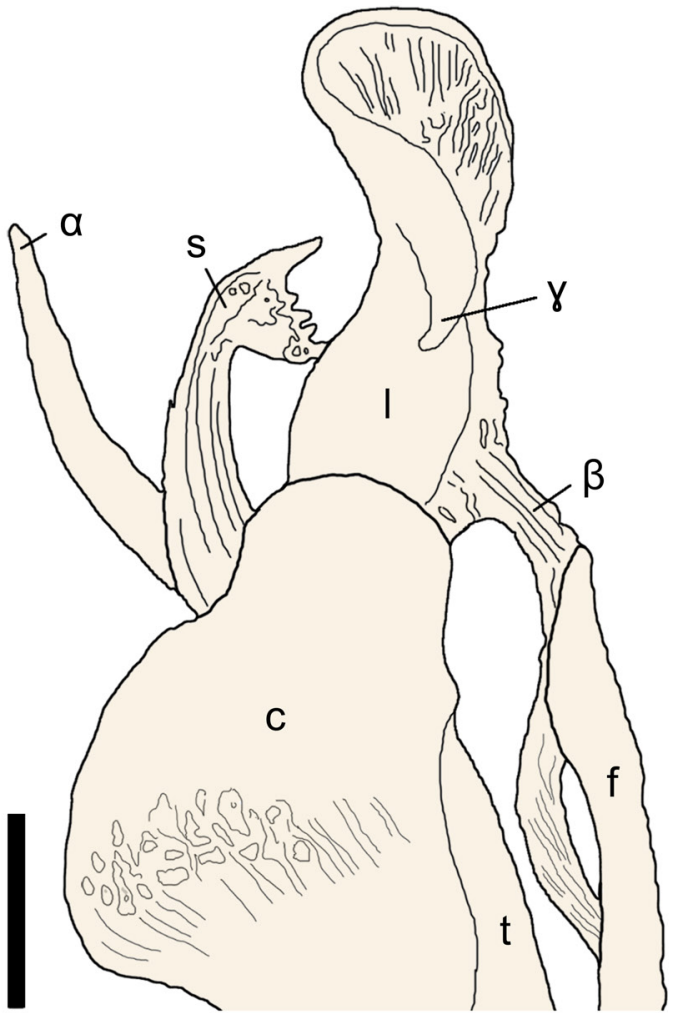

C

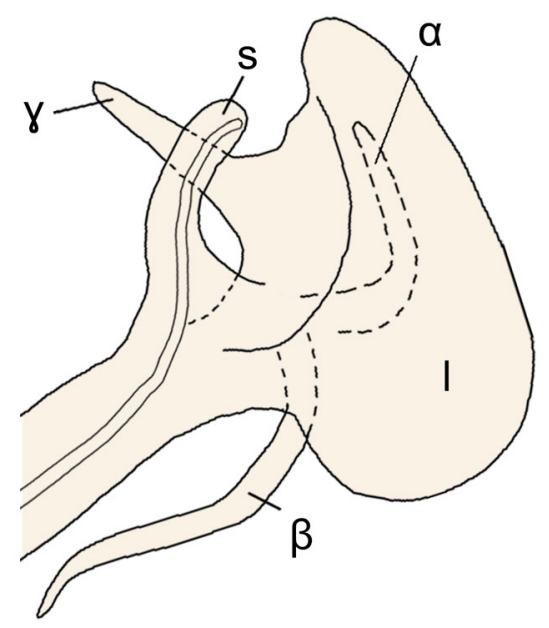

$\mathrm{D}$

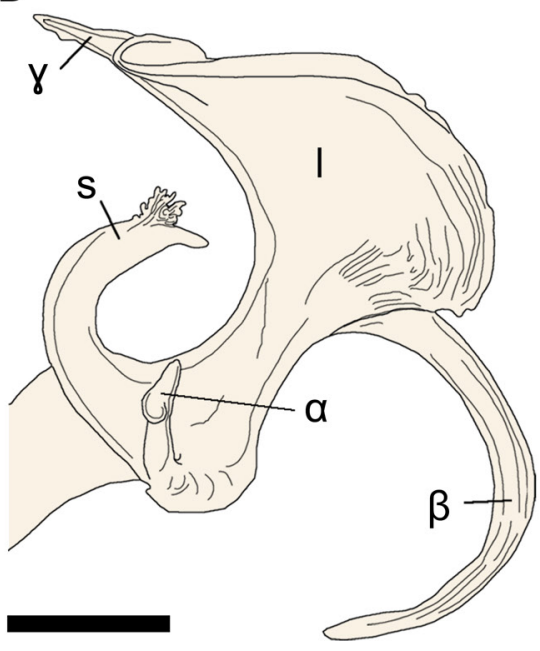

B

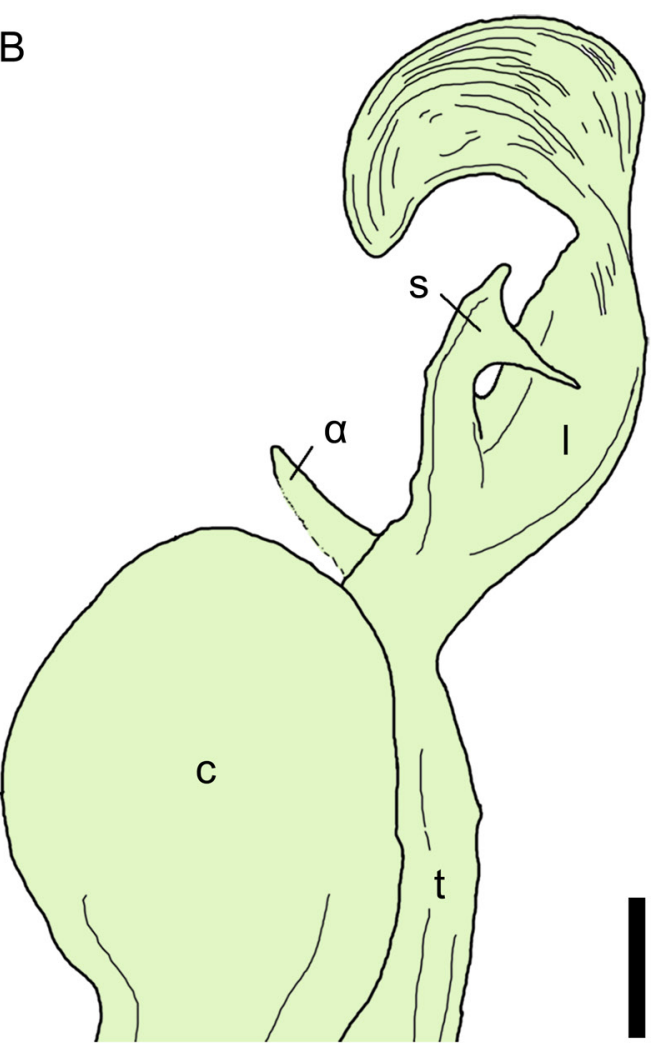

$\mathrm{E}$

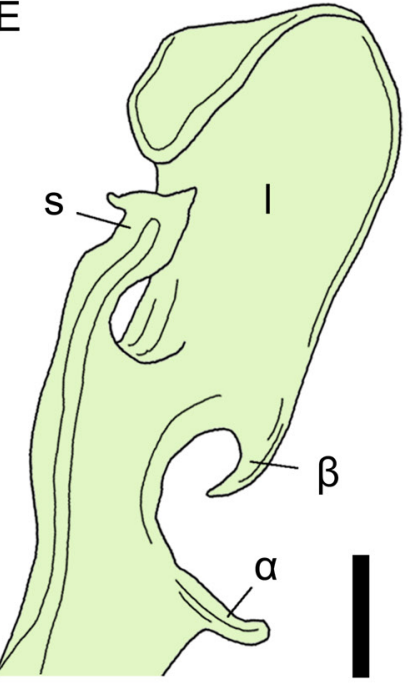

Fig. 6. Telopodite and gonocoxite of Lusitanipus alternans and Lusitanipus xanin sp. nov. A. Distal part of gonopod of Lusitanipus alternans in anterior view, redrawn after Reboleira \& Enghoff (2015). B. Distal part of gonopod of Lusitanipus xanin sp. nov. in anterior view. C. Tip of telopodite of Lusitanipus alternans in lateral view, redrawn after Verhoeff (1900) (original without scale bar). D. ip of telopodite of Lusitanipus alternans in ventrolateral view, redrawn after a SEM photograph by Reboleira \& Enghoff (2015). E. Tip of telopodite of Lusitanipus xanin sp. nov. in lateral view. Scale bars $=0.1 \mathrm{~mm}$. Abbreviations: $\alpha, \beta$ and $\gamma=$ processes of telopodite; $c=$ gonocoxite; $f=$ pseudoflagellum (or hornflagellum); $l=$ lamella; $s=$ solenomerite; $t=$ telopodite. 
Lusitanipus xanin sp. nov. was first collected in a small cave near its entrance, and the other collections were made under stones in the surface. This species may be considered a troglophile, like several other callipodidan species (Stoev \& Engoff 2006, Kime \& Enghoff 2011). On the surface, Lusitanipus xanin sp. nov. was collected under stones in a zone with soil, stony debris, and gravel; therefore, like other species of the order it could be considered petrophile. The collection points were located in the lower part of a slope under a limestone outcrop. These slopes feature scree fields, so it is possible that this species could be found in the MSS as other troglophile Iberian millipede species (Gilgado et al. 2015a, 2015b, 2017, Akkari et al. 2018). This is only the fourth described species of the order Callipodida in the Iberian Peninsula. However, given the rising interest in diplopodology, it is very likely that in the years to come new species will be described, thus providing a better understanding of the distribution and biology of this group in the region.

\section{Acknowledgements}

We would like to thank Begoña Sánchez Chillón for providing us with the reference numbers for the MNCN collection, and to Lucía Maltez for proofreading and improving the English of our manuscript. We are also grateful to one anonymous referee, Pavel Stoev and the topical entomology editor of the EJT, Nesrine Akkari, for reviewing and helping us to improve our manuscript.

\section{References}

Abril Hurtado J., Pliego Dones D. \& Rubio Navas J. 1982. Mapa Geológico de España, escala 1:50.000, $2^{a}$ Serie (MAGNA). Hoja de Silván, 191 (10-10). IGME, Madrid.

Akkari N. \& Enghoff H. 2012. Review of the genus Ommatoiulus in Andalusia, Spain (Diplopoda: Julida) with description of ten new species and notes on a remarkable gonopod structure, the fovea. Zootaxa 3538 (1): 1-53. https://doi.org/10.11646/zootaxa.3538.1.1

Akkari N. \& Enghoff H. 2017. Revision of the genus Ommatoiulus Latzel, 1884 (Julida, Diplopoda) in Portugal, with description of six new species. European Journal of Taxonomy 295: 1-42. https://doi.org/10.5852/ejt.2017.295

Akkari N., Gilgado J.D., Ortuño V.M. \& Enghoff H. 2018. Out of the dark void: Ommatoiulus longicornis n. sp., a new julid from Spain (Diplopoda, Julida) with notes on some troglobiomorphic traits in millipedes. Zootaxa 4420 (3): 415-429. https://doi.org/10.11646/zootaxa.4420.3.7

Brewer M.S., Sierwald P. \& Bond J.E. 2012. Millipede taxonomy after 250 years: classification and taxonomic practices in a mega-diverse yet understudied arthropod group. PLoS One 7 (5): e37240. https://doi.org/10.1371/journal.pone.0037240

Cárcamo H.A., Abe T.A., Prescott C.E., Holl F.B. \& Chanway C.P. 2000. Influence of millipedes on litter decomposition, $\mathrm{N}$ mineralization, and microbial communities in a coastal forest in British Columbia, Canada. Canadian Journal of Forest Research 30 (5): 817-826. https://doi.org/10.1139/x00-014

Causey N.B. 1955. Spirobolidae (Spirobolida: Diplopoda) east of the Rocky Mountains. Journal of the Kansas Entomological Society 28 (2): 69-80.

Climate-data.org 2019. Villafranca del Bierzo (León, Spain). Available from https://es.climate-data.org/europe/espana/castilla-y-leon/villafranca-del-bierzo-143882/[accessed 3 Apr. 2019].

David J.F. 2015. Diplopoda-Ecology. In: Minelli A. (ed.) Treatise on Zoology-Anatomy, Taxonomy, Biology. The Myriapoda, Volume 2: 303-327. Brill, Leiden-Boston.

https://doi.org/10.1163/9789004188273_013 
Díaz González T.E. \& Penas A. 2017. The High Mountain Area of Northwestern Spain: The Cantabrian Range, the Galician Leonese Mountains and the Bierzo Trench. In: Loidi J. (ed.) The Vegetation of the Iberian Peninsula, Plant and Vegetation 12, Volume 1: 252-321. Springer International Publishing, Cham. https://doi.org/10.1007/978-3-319-54784-8_7

Djursvoll P. 2019. Two new species of Polydesmus Latreille, 1802-1803 from northern Spain with reinstatements of two species, and a key to the Iberian Polydesmus species (Diplopoda, Polydesmida, Polydesmidae). ZooKeys 888: 51-65. https://doi.org/10.3897/zookeys.888.37816

Enghoff H. \& Reboleira A.S.P.S. 2013. A new cave-dwelling millipede of the genus Scutogona from central Portugal (Diplopoda, Chordeumatida, Chamaesomatidae). Zootaxa 3736 (2): 175-186.

https://doi.org/10.11646/zootaxa.3736.2.5

Gilgado J.D., Enghoff H., Tinaut A., Mauriès J.-P. \& Ortuño V.M. 2015a. Sierra Nevada (Granada, Spain): a high-altitude biogeographical crossroads for millipedes (Diplopoda), with first data on its MSS fauna and description of a new species of the genus Ceratosphys Ribaut, 1920 (Chordeumatida: Opisthocheiridae). Zootaxa 4044 (3): 391-410. https://doi.org/10.11646/zootaxa.4044.3.4

Gilgado J.D., Enghoff H., Tinaut A. \& Ortuño V.M. 2015b. Hidden biodiversity in the Iberian Mesovoid Shallow Substratum (MSS): New and poorly known species of the millipede genus Archipolydesmus Attems, 1898 (Diplopoda, Polydesmidae). Zoologischer Anzeiger 258: 13-38.

https://doi.org/10.1016/j.jcz.2015.06.001

Gilgado J.D., Ledesma E., Enghoff H., Mauriès J.-P. \& Ortuño V.M. 2017. A new genus and species of Haplobainosomatidae (Diplopoda: Chordeumatida) from the MSS of the Sierra de Guadarrama National Park, central Spain. Zootaxa 4347 (3): 492-510. https://doi.org/10.11646/zootaxa.4347.3.4

Golovatch S.I. \& Kime R.D. 2009. Millipede (Diplopoda) distributions: A review. Soil Organisms 81 (3): 565-597.

Hoffman R.L. 2009. The female of Cyphocallipus excavatus Verhoeff, 1909 (Callipodida: Cyphocallipodidae). Contributions to Natural History 12: 643-649.

Kime R.D. \& Enghoff H. 2011. Atlas of European Millipedes (Class Diplopoda): Volume 1, Orders Polyxenida, Glomerida, Platydesmida, Siphonocryptidae, Polyzoniida, Callipodida, Polydesmida. Pensoft, Sofia-Moscow.

Kime R.D. \& Enghoff H. 2017. Atlas of European millipedes 2: Order Julida (Class Diplopoda). European Journal of Taxonomy 346: 1-299. https://doi.org/10.5852/ejt.2017.346

Loomis H.F. 1976. Some Blue-Green Rhachodesmid Millipeds of Mexico Related to Stronglylodesmus Saussure. Florida Entomologist 59 (4): 397-402. https://doi.org/10.2307/3494189

Mauriès J.-P. 2013. Trois espèces nouvelles de diplopodes cavernicoles de l'Andalousie (Espagne) (Diplopoda: Polydesmida: Polydesmidae; Chordeumatida: Vandeleumatidae, Opisthocheiridae). Artrhopoda Selecta 22 (2): 97-112. https://doi.org/10.15298/arthsel.22.2.01

Mauriès J.-P. 2014. Quatre espèces nouvelles de Diplopodes cavernicoles de l'Andalousie (Espagne) (Diplopoda: Polydesmida; Polydesmidae; Chordeumatida: Chamaesosomatidae, Opistocheiridae). Arthropoda Selecta 23 (1): 33-50. https://doi.org/10.15298/arthsel.23.1.03

Mauriès J.-P. 2018. Le genre Hirudisoma Fanzago, 1881 dans la péninsule Ibérique: description de deux espèces atypiques, Hirudisoma espadanensis n. sp. et H. brusteli n. sp. du Levant d'Espagne (Diplopoda, Polyzonida, Hirudisomatidae). Bulletin de la Société d'histoire naturelle de Toulouse 154: 41-55.

Mesibov R. 2017. Iulomorphid millipedes (Diplopoda, Spirostreptida, Iulomorphidae) of Tasmania, Australia. ZooKeys 652: 1-36. https://doi.org/10.3897/zookeys.652.12035 
Reboleira A.S.P.S. \& Enghoff H. 2014. Sireuma, a new genus of subterranean millipedes from the Iberian Peninsula (Diplopoda, Chordeumatida, Opisthocheiridae). Zootaxa 3785 (1): 79-86. https://doi.org/10.11646/zootaxa.3785.1.6

Reboleira A.S.P.S. \& Enghoff H. 2015. Redescription of Lusitanipus alternans (Verhoeff, 1893) (Diplopoda, Callipoda, Dorypetalidae) and ecological data on its Laboulbeniales ectoparasites in caves. Zootaxa 3957 (5): 567-576. https://doi.org/10.11646/zootaxa.3957.5.5

Recuero E. \& Rodríguez-Flores P.C. 2020. A new Mediterranean species of Dolistenus (Diplopoda, Platydesmida, Andrognathidae), with an updated key for the genus and the first contribution for a barcode database of European Platydesmida. Zootaxa 4718 (1): 123-133.

https://doi.org/10.11646/zootaxa.4718.1.10

Rivas-Martínez S., Rivas-Sáenz S. \& Penas A. 2011. Worldwide bioclimatic classification system. Global Geobotany 1: 1-634.

Spelda J. 2015. Order Callipodida. Revista IDE@-SEA, 25B:1-12. Available from http://sea-entomologia.org/IDE@/revista_25B.pdf ISSN 2386-7183 [accessed 3 Aug. 2020]

Stoev P. 2015. Order Callipodida. In: Minelli A. (ed) Treatise on Zoology-Anatomy, Taxonomy, Biology. The Myriapoda, vol. 2: 420-426. Brill, Leiden-Boston. https://doi.org/10.1163/9789004188273_017

Stoev P. \& Enghoff H. 2006. A review of the millipede genus Dorypetalum Verhoeff, 1900 (Diplopoda: Callipodida: Dorypetalidae). Zootaxa 1254 (1): 29-43. https://doi.org/10.5281/zenodo.173059

Stoev P., Sierwald P. \& Billey A. 2008. An annotated world catalogue of the millipede order Callipodida (Arthropoda: Diplopoda). Zootaxa 1706 (1): 1-50. https://doi.org/10.11646/zootaxa.1706.1.1

Verhoeff C. 1893. Neue Diplopoden der portugiesischen Fauna. Zoologischer Anzeiger 16: 161-169.

Verhoeff C. 1900. Beiträge zur Kenntniss paläarktischer Myriopoden. X. Aufsatz: Zur vergleichenden Morphologie, Phylogenie, Gruppen- und Art-Systematik der Lysiopetaliden. Zoologische Jahrbücher Abteilung für Systematik, Ökologie und Geographie der Tiere 13 (1): 36-70.

Wesener T. \& Wagele J. 2008. The giant pill-millipedes of Madagascar: revision of the genus Zoosphaerium (Myriapoda, Diplopoda, Sphaerotheriida). Zoosystema 30 (1): 5-85.

Manuscript received: 14 April 2020

Manuscript accepted: 19 May 2020

Published on: 8 September 2020

Topic editors: Rudy Jocqué and Nesrine Akkari

Desk editor: Jeroen Venderickx

Printed versions of all papers are also deposited in the libraries of the institutes that are members of the EJT consortium: Muséum national d'Histoire naturelle, Paris, France; Meise Botanic Garden, Belgium; Royal Museum for Central Africa, Tervuren, Belgium; Royal Belgian Institute of Natural Sciences, Brussels, Belgium; Natural History Museum of Denmark, Copenhagen, Denmark; Naturalis Biodiversity Center, Leiden, the Netherlands; Museo Nacional de Ciencias Naturales-CSIC, Madrid, Spain; Real Jardín Botánico de Madrid CSIC, Spain; Zoological Research Museum Alexander Koenig, Bonn, Germany; National Museum, Prague, Czech Republic. 